第 1 表 倍數個體の特性調查成績

\begin{tabular}{|c|c|c|c|c|c|}
\hline & & & & 向 & 葵 \\
\hline & 二 倍 體 & 四 倍體 & 八倍體 & 二 倍 體 & 四倍體 \\
\hline $\mathrm{cm}$ & 73.5 & 92.0 & 114.6 & 136.5 & 200.0 \\
\hline 比 數 & 100 & 125 & 155 & 100 & 146 \\
\hline $\mathrm{cm}^{2}$ & 23.8 & 36.7 & 31.4 & 346.2 & 439.9 \\
\hline 染 四 積 & 100 & 154 & 131 & 100 & 127 \\
\hline $\mathrm{mm}$ & 0.31 & 0.40 & 0.47 & 0.42 & 0.56 \\
\hline 染 の 厚 d & 100 & 129 & 151 & 100 & 133 \\
\hline 長 き & 12.0 & 13.6 & 15.8 & 22.4 & 24.8 \\
\hline 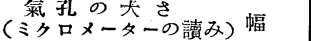 & 9.3 & 12.0 & 13.4 & 14.3 & 18.7 \\
\hline 比 數 & 100 & 146 & 189 & 100 & 144 \\
\hline 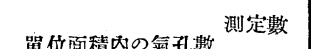 & 26.2 & 15.8 & 18.6 & 21.5 & 13.9 \\
\hline 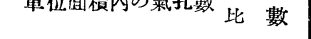 & 100 & 60 & 70 & 100 & 64 \\
\hline 花の㚐さ & & & & 17.3 & 24.8 \\
\hline （直 徑） & & & & 100 & 143 \\
\hline 長 & 9.2 & 10.7 & 11.4 & & \\
\hline (花粉粒の大ざ & 6.5 & 8.1 & 9.2 & & \\
\hline 比 數 & 100 & 144 & 175 & & \\
\hline 開花始め迄の日數 & 29 & 27. & 34 & 93 & 79 \\
\hline 種子數 ( 1 株) 實 數 & 345.6 & 478.2 & 296 & 296.4 & 285.7 \\
\hline 比 數 & 100 & 138 & 85 & 100 & 96 \\
\hline 種子の重量 (1 株) $\mathrm{gm}$ & 9.4 & 13.9 & 12.4 & 97.5 & 192.4 \\
\hline 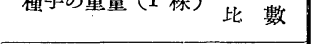 & 100 & 147 & 131 & 100 & 197 \\
\hline 種子の 100 粒重 $\mathrm{gm}$ & 2.8 & 3.9 & 4.6 & 3.6 & 7.2 \\
\hline 比 數 & 100 & 139 & 164 & 100 & 200 \\
\hline
\end{tabular}

Hideto Ока 1942. Biochemical studies of the autotetraploid tomato. Jap. Jour. Genet. 18: 118-121.

\title{
蕃茄同質倍數體 の生化學的研究
}

$$
\text { 阙英人 }
$$

東京帝國大學農學部栽培學研究室

植物に於て染色體數の量的變化は形態學的, 細胞學的並に生理學的性質に遺傳的變異を條件附 けるものである。著者は蕃荕の同質四倍體に就いて生化學的見地から觀察を行つた。 
（1）Chrolophyll 含量 倍數體は一般に葉が厚く且つ濃綠となるが其等を测定して見ると 第 1 表に示す如く, 葉は 35-40\%, 單位面積に於ける葉綠素含量は 10-1.1\% 四倍體が增加して 居る。葉綠素の增加は炭酸同化作用と深い閯係がある。

第 1 表 單位面積中に於ける葉の Chlorophyll 含量

\begin{tabular}{|c|c|c|c|c|c|c|}
\hline 種 類 測 定 日 & 葉厚比率 & 7 月 7 日 & 7 月 13 日 & 7 月 20 日 & 本 均 & 比率 \\
\hline $2 n$ L.esculentum & 1.00 & $11.62 \mathrm{mg}$ & $12.33 \mathrm{mg}$ & $12.35 \mathrm{mg}$ & $12.10 \mathrm{mg}$ & 100 \\
\hline $4 n$ L. esculentum & 135 & 12.06 & 14.13 & 14.30 & 13.49 & 111 \\
\hline $2 n$ L.pimpinellifolium & 100 & 12.46 & 17.55 & 17.32 & 15.77 & 100 \\
\hline $4 n$ L.pimpinellifolium & 140 & 13.52 & 19.24 & 19.41 & 17.39 & 11.0 \\
\hline
\end{tabular}

（2） 細胞汁液澧度 䓞糖液（Mol）中にて葉の 氣孔孔邊細胞に 起る原形質分離によつて觀察 した結果は第 2 表に示す如く, 四倍體はいつれも0.1-0.2M それぞれ原種 (diploid) より低下し て居る。滲等嬮の低下は四倍體の生理作用に重大な影響を與へるものである。

第 2 表 葉の細胞汁液濃度 (原形質分離による)

\begin{tabular}{|c|c|c|c|c|c|c|c|}
\hline 種 類 & $0.35 \mathrm{M}$ & $0.40 \mathrm{M}$ & $0.45 \mathrm{M}$ & $0.50 \mathrm{M}$ & $0.55 \mathrm{M}$ & $0.60 \mathrm{M}$ & $0.65 \mathrm{M}$ \\
\hline $2 n$ L.esculentum & - & - & - & - & - & $T$ & + \\
\hline $4 n$ L. esculentum & - & $T$ & + & + & H & H & m \\
\hline $2 n$ L.pimpinellifolium & - & - & - & $T$ & - & + & H \\
\hline $4 n$ L.pimpinellifolium & - & $T$ & + & + & $H$ & $H$ & \# \\
\hline
\end{tabular}

一分離起さす，十僅加に起方, 十稍々强く起す, 井强く起す

（3）新鮮・乾物重量及含水率 葉の單位面積に於ける新鮮重量を示すと第 3 表の如く, 四倍體 は 22-44\%, 乾物重子亦 16-26\%, 夫々增加して居る。含水量に於ても四倍體は 0.8-3.4\% 原種 より高くなつて居り此の事は四倍體の細胞汁液濃度が低下して居る事實と良く一致する。

第 3 表 葉の單位面積に於ける新鮮·乾物重及含水率

\begin{tabular}{|c|c|c|c|c|c|}
\hline 新鮮·乾物重 & 新 & 蘚 & 乾 & 重 & \\
\hline 種 類 & 重 量 & 比 率 & 重 量 & 此 率 & 公水 \\
\hline $2 n$ L.esculentum & $3.560 \mathrm{~g}$ & 100 & $0.5626 \mathrm{~g}$ & 100 & 84.2 \\
\hline $4 n$ L.esculentum & 4.370 & 122 & $0.65 \tilde{72}$ & 116 & 85.0 \\
\hline $2 n$ L.pimpinellifolium & 2.320 & 100 & 0.4323 & 100 & 81.4 \\
\hline $4 n$ L.pimpinellifolium & 3.360 & 144 & 0.5127 & 118 & 84.8 \\
\hline $2 n$ hybrid & 2.510 & 100 & 0.3885 & 300 & 84.6 \\
\hline $4 n$ hybrid & 3.490 & 139 & 0.4894 & 126 WU: & 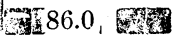 \\
\hline
\end{tabular}

單位面積 67.96 平方糧, hybrid $=$ L. esculentum $\times$ L. pimpinellifolium. 
（4）崖酸同化作用 炭酸同化作用の測定方法には色々あるが, 此處では 1 日中に於ける一定面 積の乾物增加量を以て測定した, 其の結果は四倍體は常に原種より乾物增加量が大である事を認 めた。此の事は四倍體の同化 機能の强化を示すもので四倍 體に於て各種の含有成分の增 加は其の同化能率の高い事に 因るものである。

(5) 無袎成分 葉の灰分 含量を測定して見ると第 4 表 に示す如く, 四倍體は 3.6一 $3.8 \%$ の增加を示して居る。

第 4 表 葉の灰分含量

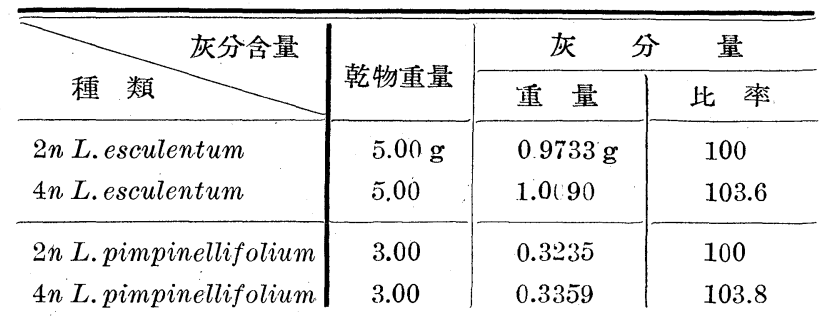

（6）Vitamin C 含量 單位面積の新鮮葉中に於けるVitamin C を測定して見ると第 5 表に 示す如く, 四倍體はいづれも 7-26\% の增加を認め得る。Vitamin C は植物の生活機能を營を上 に重要な役割を持つものであるから Vitamin C の增加は四倍體の生化學的作用に著るしい影響 を與へる事は想像に難くない。

第 5 表 葉の單位面積中に於けるVitamin C 含量

\begin{tabular}{|c|c|c|c|c|}
\hline \multirow{2}{*}{ 種 類 } & \multicolumn{2}{|c|}{7 月 17 日（夏期栽培） } & \multicolumn{2}{|c|}{9 月 14 日（秋期栽培） } \\
\hline & Vitamin $\mathrm{C}$ & 比率 & Vitamin $\mathrm{C}$ & 比 率 \\
\hline $2 n$ L.esculentum & $44.6 \mathrm{mg}$ & 100 & $71.3 \mathrm{mg}$ & 100 \\
\hline $4 n$ L.esculentum & 54.0 & $1: 1$ & 90.3 & 126 \\
\hline $2 n$ L.pimpinellifolium & 45.4 & 100 & 90.3 & 100 \\
\hline $4 n$ L.pimpinellifolium & 55.8 & 122 & 97.3 & 107 \\
\hline
\end{tabular}

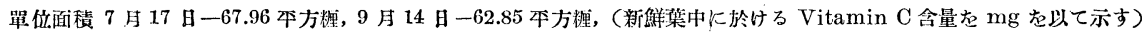

（7） Peroxidase の活性度 peroxidase の活性度の測定方法は色々あるが，本實驗ではプルプ ロガリン法とグアヤコール法によつた, 測定結果は第 6 表に示す如く L. esculentum 及雜種に於 ては四倍體の方が著るしく高いが, L. pimpinellifolium では逆に四偣體の方が低くなつて居る。 peroxidase は植物の生理作用中特に生長, 呼吸作用等々深心關俰を持つるのである。

第 6 表 葉の單位面積中に於的る過酸化酸素活性度

\begin{tabular}{|c|c|c|c|c|}
\hline 酸素含量 & \multicolumn{2}{|c|}{7 月 18 日 (夏期栽培) } & \multicolumn{2}{|c|}{9 月 26 日（秋期截培） } \\
\hline 種 類 & プルプロガリン量 & 比 率 & グアヤコール量 & 比率 \\
\hline $2 n$ L.esculentum & $12 . \tilde{E} 0 \mathrm{mg}$ & 100 & $1.275 \mathrm{mg}$ & 100 \\
\hline $4 n$ L.esculentum & 38.50 & 308 & 2.304 & 180 \\
\hline $2 n$ L.pimpinellifolium & 38.00 & 100 & 2.640 & 100 \\
\hline $4 n$ L.pimpinellifolium & 10.25 & 26.9 & 1.540 & 58.3 \\
\hline $2 n$ hybrid & 16.75 & 100 & 1.242 & 100 \\
\hline $4 n$ hybrid & 24.00 & 143.2 & 2.940 & 236 \\
\hline
\end{tabular}

プルプロガリン法ー67.96 本方糎. グアヤコール法一新鮮重 1 瓦中 


\title{
結
}

\section{論}

蕃茄同質四倍體の 生化學的性質は原種（diploid）のそれと著るしく異つて居るものである。 Müntzing（'36）は「倍數體は新しき生理學的性質新しき反應の基準を持つ」と云ひ又 Kostoff （'38）は「倍數植物は新しい生物學的體系 (biological system) を持つ」と云つて居るが本實驗 結果は此等諸氏の說の正しい事を裏書きするものである。

Yosito Yamazaki and Masahito Ishinara 1942. Polyploid plants from twin seedlings in the common wheat and their local differences in nature. Jap. Jour. Genet. 18: $121-122$.

\section{普通小麥の双生兒に件ふ倍數體發現の 地域的差異に關する䂭究（豫報）}

\author{
川崎義人・石原正仁
}

植物の双生兒に關しては, Leeuwenhoeck が 1719 年にオレンヂの一種について發見報告して 以來, 相當多數の業蹟が發表せられてるるが, 1933 年に Ramiah が稻に就て, Kappert が亞麻 について双生兒の分體の一方が牛數體のものを發見し，1934 年に並河・川上が普通小麥の双生兒 の一方の分體が卅數體のもの〉外に, 3 倍體及 4 倍體よりなるものを發見して以來, この方面の 研究が著しく進涉し, 双生兒に伴ふ牛數體及び倍數體に關する研究報告は今日迄 20 編以上を數 ふるに至つたのであるが，これ等の論文は，主として次の 4 つの問題を取扱つたものである。郎 ち（1）双生兒並これに件ふ倍數性は如何なる植物に如何なる程度に發現するものであるか, 又 この發現は同一植物中の品種或は系統によつて如何なる程度に異なるものであるかる研究せる もの，(2）双生兒及これに件ふ倍數性發現の原因及其の機構を研究せるもの，(3) 双生兒より 牛數體及倍數體を得て, これを細胞學的に研究し, 其の植物のゲノム構成を研究せるもの及 (4) 双生兒より實用的に有利な倍數植物を得んとせるもの,である。佮これ等の研究結果より双生兒 及これに件ふ倍數性の發現程度が環境によつても影響せられるであらうと推察されるが,この問 題に關しては計畫的に取扱つたものは未だ見ない樣である。故に筆者は育成過程の明らかな普 通小麥農林 4 號を供試し, 異なれる地域に 生產された種子について双生兒及これに件ふ牛數體 及倍數體の發現程度を比較檢討した。

農林 4 號は 1924 年に愛媛縣農事試驗場に於て優勝旗 347 號を母とし, 廣島シプレー 3 號を父 として交配を行ひ， $\mathrm{F}_{3}$-seed を農事試驗場鴻巢試驗地に移して選拢を加へ，其の後 $\mathrm{F}_{4}$-seed を岡 山縣農事試驗場に移し, 爾來此所に於て選拔育成され 1931 年 $\mathrm{F}_{z}$-plant の時代に農林 4 號々命名 せられたるものであるが，同年には廣島縣農事試驗場に，1932 年には奈良縣農事試驗場に，1934 年には島根縣農事試驗場に夫れ夫れ種子を配布し, 爾來これ等の地方に於て每年採種せられたも のである。

上記 4 地方の內岡山に關しては 1938,1939 及 1940 年生產の $F_{15}, F_{16}$ 友 $F_{1 i}$-seed に就き，廣 島に關しては 1939 及 1940 年生產の $\mathrm{F}_{18}$ 及 $\mathrm{F}_{17}$-seed に就き，奈良に關しては $1935,1938,1939$ 